\title{
A SUMMARY OF KALECKIAN AND KALDORIAN MODELS ON INCOME DISTRIBUTION
}

\section{Fatma Pinar ARSLAN ${ }^{1}$}

\begin{abstract}
There are two main lines of theories about income distribution, following the seminal papers of Kalecki and Kaldor. These two theories have different aspect in terms of their assumptions about competitive characteristics of market, capital utilization, market imperfections and the role of government. Several studies are designed to develop these two theories and some studies use assumptions of both theories in order to explain the income distribution. This article includes a summary of Kaleckian and Kaldorian models; their assumptions and recent contributions to these models.
\end{abstract}

Keywords: Factor income distribution, market structure, household saving, government debt

JEL Classification: D33, D40, D14, H63

\section{GELİR DAĞILIMI ÜZERINNE KALECKIYYEN VE KALDORCU MODELLERIN BİR ÖZETİ}

\section{Öz}

Gelir dağılımı üzerine, Kalecki ve Kaldor'un öncülük ettiği ve başkaları tarafından geliştirilen iki ana teori vardır. Bu teoriler piyasanın rekabetçi özellikleri, sermaye kullanımı, piyasa aksaklıkları ve kamu sektörünün rolü ile ilgili farklı varsayımlar üzerine kuruludur. Bu teoriler başka çalışmalarda geliştirilmiştir; ayrıca iki teorik çizgiden de bazı parçalar alan çalışmalar mevcuttur. Bu makale, Kalecki ve Kaldor'un modellerinin, bunların varsayımlarının ve bu modellere yapılan katkıların bir özetini sunmaktadır.

Anahtar Kelimeler: Faktör gelir dağılımı, piyasa yapısı, hanehalkı tasarrufu, kamu borcu

JEL Sinıflaması: D33, D40, D14, H63

\section{Introduction}

There are two main lines of thought in theories on income distribution: the Kaleckian approach and Kaldorian approach (also named as Cambridge approach). Kaleckian approach is based on the studies of Kalecki $(1938,1954)$. Kaldorian approach is based on the seminal paper of Kaldor (1955) and developed by Pasinetti (1962, 1989).

Kaleckian models assume monopolistic competition and endogenous capacity utilization. A mark-up is added to the price. The mark-up rate is determined by the level of monopoly in the market and the bargaining power of firms and labour unions in labour market. Kaleckian models include labour market imperfections and class struggle.

Thus, respective bargaining power of firms and workers in the labour market affect the markup rate, hence the income distribution. In the original model, saving propensities are not defined as variables. In recent Kaleckian models, the savings by different groups of income are included as in Kaldorian models.

1 Dr., Istanbul Medeniyet University, Department of Public Finance, Turkey, fatma.arslan@medeniyet.edu.tr, ORCID: 0000-0003-4596-165X 
The Kaldorian models, on the other hand, assume perfect competition and full capital utilization or fixed rate of capital utilization in the long run. Kaldorian models equate the growth rate to the capital accumulation rate and define the growth of macroeconomic variables with respect to that rate. Growth affects the aggregate demand. In these models, the output is divided into wage share and profit share. The households are grouped into capitalists and workers, with different propensities to save and with different types of income. The propensities to save by different groups of households are important variables for income distribution and economy as a whole. The different groups of income do not only represent different propensities to save, but also different levels of ownership of assets.

Government sector is introduced in models following the Kaldorian tradition. In these model, the government spending is assumed to increase the profit share and support the aggregate demand, hence growth.

There are studies on income distribution which include some aspects from either or both of these two schools of thought. This study gives a brief summary of these theories. Section 2 summarizes the seminal paper of Kalecki and mentions some recent contributions to this theory. Section 3 analyses the Kaldorian school of thought. Section 4 mentions some studies which cannot be classified within these groups but focus on the income distribution with respect to the public debt. Section 5 concludes.

\section{Kaleckian Framework of Income Distribution}

Kalecki (1938) focuses on the share of manual labour in the national income, aiming to analyse the distribution of product of industry between profits, wages and salaries. Salaries are the payments to directors, managers etc. in the industry and they are included in profits. Payments to the manual labour, on the other hand, are named as wages. The author constructs a model to examine the distribution of income in such an economy. The degree of monopoly in the industry is an important variable in this model.

According to the model, the short-term marginal cost, $m$, is:

$m=d_{m}+s_{m}+w_{m}+r_{m}$

where $d_{m}, s_{m}, w_{m}$, and $r_{m}$ are the short-term marginal costs of depreciation, salaries, wages and raw materials, respectively. Price, $p$, on the other hand, is:

$p=c_{a}+d_{a}+s_{a}+w_{a}+r_{a}$

where $c_{a}$ is the average capitalist income and $d_{a}, s_{a}, w_{a}$, and $r_{a}$ are average costs of depreciation, salaries, wages and raw materials, respectively. The difference between price and marginal cost of one unit of good is thus:

$p-m=c_{a}+\left(d_{a}-d_{m}\right)+\left(s_{a}-s_{m}\right)+\left(w_{a}-w_{m}\right)+\left(r_{a}-r_{m}\right)$

and the degree of monopoly, $\mu$, is calculated by the following equation:

$\mu=\frac{p-m}{p}$ 
When Eq. (2) is substituted in the Eq. (1), multiplied by the amount of output, $x$, and aggregated for the whole industry, the following equation is obtained:

$\sum x p \mu=\sum x c_{a}+\sum x\left(d_{a}-d_{m}\right)+\sum x\left(s_{a}-s_{m}\right)+\sum x\left(w_{a}-w_{m}\right)+\sum x\left(r_{a}-r_{m}\right)$

The author simplifies Eq. (3) according to the following assumptions:

- Marginal depreciation is smaller than average depreciation. Therefore $\sum x\left(d_{a}-d_{m}\right)$ can be simplified as $D(1-\alpha)$, where $\alpha$ is a small positive fraction and $D$ is the aggregate depreciation. The same is valid for $\sum x\left(s_{a}-s_{m}\right)$, which is simplified as $S(1-\beta), S$ being the aggregate salary.

- $\sum x\left(w_{a}-w_{m}\right)$ can be positive or negative with respect to aggregate wages $W$, related to the average wage-cost curve of the related industry. The author simplifies $\sum x\left(w_{a}-w_{m}\right)$ to $\gamma W$, where $\gamma$ is a small positive or negative fraction.

- Average cost of raw materials is assumed to be constant. Hence $\sum x\left(r_{a}-r_{m}\right)$ is replaced by 0 .

- $D \alpha+S \beta-\gamma W$ is assumed to be 0 .

When these assumptions are applied, Eq. (3) simplifies to:

$\sum x p \mu=C+D+S$

and when both sides are divided by aggregate turnover, $T=\sum x p$, left-hand side of the equation gives the average of degree of monopoly power $(\mu)$ :

$(\mu)=\frac{C+D+S}{T}$

(5)

The shares of $C, D$, and $\mathrm{S}$ to the national income can be simply found by multiplying two sides of Eq. (5) with ratio of turnover to gross income, $T / Y$, as follows:

( $\mu) \frac{T}{Y}=\frac{C+D+S}{Y}$

Kalecki (1938) claims that the relative shares of capitalists' income, salaries and depreciation in total income are dependent on the average degree of monopoly and the turnover ratio. The share of wages in national income can be driven from Eq. (6) as:

$\frac{W}{Y}=\frac{Y-(C+D+S)}{Y}$

Then, the relationship between mark-up rate and turnover ratio is given by:

$\frac{W}{Y}=1-(\mu) \frac{T}{Y}$

The share of wages in national income is negatively related with the degree of monopoly and the turnover ratio (Eq. (8)). The degree of monopoly and the turnover ratio are not independent, they are negatively related. 
Kalecki (1938) asserts that in the long run the degree of monopoly has a tendency to increase. This is to say that the share of wages decreases, whereas the share of capitalists' income and salaries rises. This claim is verified by the data of Great Britain economy, covering 1880-1913 (Kalecki, 1938).

Kaleckian approach to the income distribution is used in several recent studies. Hein (2007) introduced debt variable to the existing model. According to the model by Hein (2007), the price is determined with respect to mark-up rate $(m)$, wage rate $(w)$ and a labour-output ratio $(l)$, which is constant up to full capacity. Therefore, the price, $p$, is given by the following equation:

$p=(1+m) w l$

and the total revenue is:

$p Y=(1+m) w L$

where $L$ is the amount of labour employed. Therefore, profits, $\Pi$, and labour income in total production are given by $m w L$ and $w L$, respectively. The profit share $h$ is given by:

$h=\frac{m w L}{P Y}=1-\frac{1}{1+m}$

As the model assumes that the capacity utilization rate $<1$, then a capital-potential output ratio, $v$, is defined, rather than capital-output ratio. The rate of capital utilization is $u$, which is equal to the ratio of real output, $Y$, to potential output, $Y^{v}$. The rate of profits, $r$, is thus given by:

$r=\frac{m w L}{p K}=\frac{m w L}{P Y} \frac{Y}{Y^{v}} \frac{Y^{v}}{K}=h u \frac{1}{v}$

Thus the rate of profits depends on the rate of capacity utilization. As mentioned above, Hein (2007) introduced debt to the model. Debt is given by some rentiers to the firms as credits. Hence the profits are split into the profit of the enterprise, $\Pi^{n}$, and the interest income of rentiers, $Z$; and debt-capital ratio, $\lambda$, is introduced to the model:

$\Pi=\Pi^{n}+Z=\Pi^{n}+i B$

$\lambda=\frac{B}{p K}$

where $i$ denotes the interest rate and $B$ denotes the stock of credit. The author suggests that the profit given to the firm will be saved totally, whereas the profit given to the rentiers will be saved in a ratio equal to the saving propensity of rentiers, which is denoted by $s_{z}$. Therefore, a higher interest rate under constant $r, \lambda$ and $s_{z}$, would decrease savings. An increase in $\lambda$ would also lead to a decrease in savings.

Hein (2018) includes a government sector and government debt in Kaleckian framework. In this model, all profits are distributed to rentiers. Rentiers also hold the government debt, and they earn financial income on this debt.

Therefore share of wages in total income is negatively correlated with share of profit in income and ratio of financial income to total income. Share of profit, on the other hand, is negatively related with the ratio of financial income to total income. 
Ünveren and Sunal (2015) analyse the reason of low labour share in total production in Turkey and find that the labour share is low due to the high concentration rates and high price markups. The study assumes a real business cycle economy with monopolistic competition. According to the results of Generalized Method of Moments (GMM) analysis performed with data of Turkish economy, the gap between the labour share in Turkey (around 30\%) and OECD (65\% in average) occur due to the mark-up rates. This result is in line with the above-mentioned Kaleckian perspective.

\section{The Cambridge Theory of Income Distribution}

The Cambridge theory of income distribution (name given by Samuelson and Modigliani, 1966) is first described by Kaldor (1955). Kaldor (1955) forms a Keynesian model on income distribution. According to the theory, the society is divided into capitalists and workers, who save some part of their incomes. The propensity to save out of profit is assumed to be higher than the propensity to save out of wage income. National income, on the other hand, is also divided in two categories: profits and wages. Different from the Kaleckian model, the wages include salaries, paid to managers etc. (in Kaleckian model, salaries and managerial pay are not included in wages, considered as a part of profits).

If the saving propensity out of profits is $s_{p}$ and saving propensity out of wage income is $s_{w}$ then the following equations hold:

$Y=W+P$

$I=S$

$S=S_{w}+S_{p}$

where $W$ denotes the total wages, $P$ denotes the total profits, $I$ denotes investment, $S$ denotes total savings, $S_{w}$ denotes savings out of wage income and $S_{p}$ denotes savings out of profit.

The shares of profit and wage in income are given by the following equations:

$$
\begin{aligned}
& \frac{P}{Y}=\frac{1}{s_{p}-s_{w}} \frac{I}{Y}-\frac{s_{w}}{s_{p}-s_{w}} \\
& \frac{W}{Y}=\frac{1}{s_{w}-s_{p}} \frac{I}{Y}-\frac{s_{p}}{s_{w}-s_{p}}
\end{aligned}
$$

If workers do not save and $s_{w}=0$, then, Eq. (9) becomes:

$$
P=\frac{1}{s_{p}} I
$$

According to the equations, distribution of income between wages and profits are dependent on the saving propensities out of wages as well as of profits and on the ratio of investment to output.

If the values of $s_{p}$ and $s_{w}$ are closer, a small change in investment-to-output ratio leads to a larger change in the income distribution. If $S_{p}=s_{w}$, the shares of wages and profits become zero. If $s_{p}<s_{w}$, the system becomes unstable. 
Pasinetti (1962) aims to continue the effort to connect the income distribution to the rate of economic growth. The author argues that the society can be grouped as "capitalists" and "workers", with different propensities to save, as in Kaldor (1955). However, Pasinetti (1962) underlines that Kaldor (1955) does not specify where the savings of workers are used.

Therefore, Pasinetti (1962) defines that savings by workers are used in production and yields interest income, as the savings of capitalists do. When profit income is assumed to be shared between workers and capitalists, the definitions by Kaldor (1955) implying the propensities to save out of wages and profits become invalid. Workers can save out of both wages and profits. Therefore, the propensities to save should be defined as workers' propensity to save, $s_{w}$; and capitalists' propensity to save, $s_{c}$.

Pasinetti (1962) replaces the variable $s_{p}$ in Kaldor (1955) with $s_{c}$ and adds more limitations to the values of $s_{w}$ and $s_{c}$ such that:

$s_{w}<\frac{I}{Y}$

to ensure that profit share is positive, and

$$
s_{c}>\frac{I}{Y}
$$

to ensure that wage share is positive.

As workers use their savings to gain profit, the following equations hold:

$Y=P_{c}+P_{w}+W$

$S=s_{w}\left(W+P_{w}\right)+s_{c} P_{c}$

$S=I$

where $P_{w}$ is the profit accrued to workers and $P_{c}$ is the profit accrued to capitalists. The profit share of capitalists thus becomes:

$$
\frac{P_{c}}{Y}=\frac{1}{s_{c}-s_{w}} \frac{I}{Y}-\frac{s_{w}}{s_{c}-s_{w}}
$$

In this model, the economy grows and the steady-state rate of return to capital is dependent on the rate of growth and the propensity of capitalists to save. The steady-state level of capital-tooutput ratio and share of capital income to total income is also dependent on capitalists' propensity to save. Workers' propensity to save does not have any effect on income distribution.

Samuelson and Modigliani (1966) criticizes the above-mentioned model of Pasinetti (1962) and name it as "Pasinetti Paradox". According to the authors, the finding by Pasinetti (1962) that saving propensity of workers do not have any impact on capital-to-output ratio and share of capital in total output is valid only under very limited conditions and can be reversed under other conditions.

The "dual theorem" defined by Samuelson and Modigliani (1966) is that when the workers' propensity to save exceeds a critical level, the rate of interest, capital-to-labour and capital-tooutput ratio and distribution of income become only dependent on workers' saving propensity and the rate of growth. 
Steedman (1972) contributes to the model of Pasinetti (1962) by including government activity to the model and claims that inclusion of government taxing and spending does not cause a qualitative change in Pasinetti's model. In the closed economy framework of Steedman (1972), workers receive transfer payments from government, in addition to wage income and profit. Government collect taxes to finance transfer payments. The budget is assumed to be balanced. The total stock of capital, $K$, consists of capital belonging to workers, $K_{W}$, and capital belonging to capitalist, $K_{C}$. Savings by workers and capitalists increases the capital share of respective group. Therefore, the following equations hold:

$$
\begin{aligned}
& \frac{d}{d_{t}} K_{W}=s_{w}\left[\left(1-t_{1}\right) W+\left(1-t_{2}\right) r K_{W}+k G\right] \\
& \frac{d}{d_{t}} K_{C}=s_{c}\left(1-t_{2}\right) r K_{C}
\end{aligned}
$$

The parameter $r$ is the rate of profit, $t_{1}$ is the rate of tax on wage income and $t_{2}$ is the rate of tax on profit income, $G$ is the government spending, and $k$ is the share of transfer payments in government spending. In the long-run, it is assumed that the growth rate of capital is equal to the growth rate, $n$, and it is the same for capitalists' and workers' share. So, the rate of profit becomes:

$$
r=n /\left(1-t_{2}\right) s_{c}
$$

The net rate of profit, $n / s_{c}$, obtained by multiplying Eq. (10) by (1- $\left.\mathrm{t}_{2}\right)$ is independent of any tax rate. Disposable income of workers, on the other hand, negatively related with $t_{1}$ and $t_{2}$

Pasinetti (1989) introduces government expenditure and taxation to the former model. In this model, a government propensity to save, $s_{T}$ is introduced and government expenditure is given as:

$$
G=\left(1-s_{T}\right) T
$$

where $s_{T}$ can be positive or negative. This model differs from Steedman (1972) model where there is no possibility of public surplus or debt. Government applies both direct taxes (on wage income, profit income) and indirect taxes (on consumption expenditures of capitalists, workers and government itself). If $s_{T}=0$, the government budget is balanced. However, as two different taxes are defined on wage income and profit income, Pasinetti (1989) introduces two different propensities to save by workers. One is workers' propensity to save out of wages and the other is workers' propensity to save out of profits. In the Cambridge equation, the profit rate, $r$, is only dependent upon the growth rate, $g_{n}$, and saving propensity to capitalists does not change. Although the gross profit rate depends on the tax rate on profit income:

$$
r=\frac{1}{s_{c}\left(1-t_{p}\right)} g_{n}
$$

the net profit rate does not depend on the tax rate, as in Steedman (1972):

$$
r\left(1-t_{p}\right)\left(1 / s_{c}\right) g_{n}
$$

In the case of government debt or surplus, the savings propensities and final saving amounts of capitalists and workers change, but the rate of profit are not affected by the government policy. 
As in the model without government, workers' saving propensity does not affect the equilibrium level of share of profits. On the other hand, the share of wages is affected by taxation.

Panico (1997) introduces the possibility of a debt-financed fiscal policy into the framework of Steedman (1972).

This modifies the Cambridge income distribution equation by introducing the tax rate. In this setup, in addition to the saving propensity of capitalists, the tax rate also influences the profit rate. As the tax rate increases, the profit rate rises.

As the model constructed by Pasinetti (1989) is a closed economy model, the public debt can only be domestic debt. When public sector borrow, the households know that there is a future liability of taxation for them and they put aside some of their savings. This reduces capital stock in the economy. Therefore, Ricardian Equivalence Theorem holds: borrowing and imposition of taxes have the same effects. It holds because in Kaldorian distribution models, saving is dependent upon constant propensities to save and it is not likely that households are able to smooth their consumption over time to meet tax requirements, as asserted by Neutrality Theorem (Barro, 1974).

Pasinetti (1989) argues that if bonds are issued by the government and households who save buy public bonds and private loans, rate of interest on these two different types of assets would be the same. Government sector would collect the same amount of money when it issues bonds and when it impose the taxes, because households would do extra saving in exactly the same amount of their future tax liability. Even if there is positive interest rate nothing changes, as the government would collect the tax to pay its debt together with the interest from households, and pay its debt to the households together with the interest.

In a Keynesian-Kaldorian growth model Palley (1997) introduces the role of goods demand in income distribution. The author assumes that the profit rate depends positively on the growth of goods demand since demand will stimulate investment. The profit rate will fluctuate in order to balance output and goods demand. If the ex-post profit rate is higher than the profit rate that assures equilibrium in the goods market, there will be excess saving. In this case, output must decrease, which implies a reduction in the ex-post rate of profit. This, in turn, implies an improvement in income distribution in favour of workers. In this setup, the saving propensity of workers is assumed to be equal to zero since the driving force is goods demand.

\section{Public Debt and Income Distribution}

The effect of government expenditure and debt are discussed in several studies. Modigliani (1961) assumes that the expansionary fiscal policy has a positive impact on consumption by households. The mechanism is simply summarized as follows: an increase in government debt to finance government expenditure, rather than an increase in taxes, leads to an increase in perceived wealth of households and triggers consumption. This results in a reduction in savings, an increase in interest rates and thus, a decrease in capital accumulation.

However, future taxes which will probably be applied to finance the government debt interest payments will reverse the wealth effect, to a certain degree (Barro, 1974). Barro (1974) argued that in an overlapping generations framework, the mechanism claimed by Modigliani will not work, because current generations will act as they are living infinitely. 
Mankiw (2000) designed a model, including saver and spender households, and claimed that government debt does not alter the steady state value of capital stock or output, but influence steady state income distribution, simply because government debt is financed by extra taxes on spenders and savers, whereas interest rate on government debt is only paid to savers. Therefore income inequality worsens. Impact of government debt on inequality can be examined by a kind of welfare measure.

Some models include wealth and consumption out of wealth. This enhances the explanatory power of the literature because people can consume from their wealth in order to smooth their consumption. If workers and capitalist save, following Pasinetti (1989), they can also consume from their corresponding wealth (Palley, 2012). Workers' propensity to consume from their wealth is assumed to be lower than capitalists' propensity to consume their wealth, as the case in propensity to consume out of income. In the model assumed by Palley (2012), propensity to consume out of wealth is lower than the propensity to consume out of income, for both workers and capitalists.

Wealth position of households can be defined with respect to their holdings of government debt and therefore, the impact of government debt on distribution can be monitored more closely. In D'Erasmo and Mendoza (2016), two groups of households are defined; both groups of households hold government debt, but they hold in different amounts: one group has less bonds in the initial state.

In general equilibrium models which include government behaviour, taxes on labour and capital income, government debt and interest payments and consumption and transfer payments of government, or a combination of these, are considered (e.g. (Flodén, 2001). Government can finance its expenditures by increasing taxes, issuing money or collecting debt from financial markets. In order to collect debt, government pays an interest rate. Government can collect debt from domestic households, who does saving (rentiers' class in Hein (2018)), from private sector or from abroad (Diamond, 1965).

Yakut \& Voyvoda (2017) construct a computable general equilibrium model, in order to assess the impact of public policies on distribution. Seven groups of representative households are defined according to their source of income. The groups are collected in two subsets: Ramseytype households who do saving and maximize their life-time utility and non-saving households who maximize their present time utility. Ramsey-type individuals make the intratemporal choice between consumption and leisure. Firms, on the other hand, consist of 11 representative firms, each one operating in a different sector. Government sector collects tax, make transfer payments to households and firms, covers social security deficits, in addition to the public expenditures. The authors include internal migration in Turkey as an important factor on wages, savings, consumption levels and distribution. The results of the study show that transfers to households leads to a decrease in labour supply, whereas government policies reduce the cost of labour increases in labour supply. 


\section{Conclusion}

Kaleckian and Kaldorian models of income distribution focus on different aspects of economy. Kaleckian models assumes monopolistic competition and attributes the income inequality to the imperfections of the market and the mark-up rate. The Kaldorian model underlines the importance of different saving rates by workers and profit-earners and explains income distribution using the different propensities to save. Government is not included in the original versions of both model, but it is added by other authors, in order to analyse the effects of government activity on income distribution.

\section{References}

Barro, R. J. (1974). Are Government Bonds Net Wealth? Journal of Political Economy, 82(6), 1095-1117. https://doi.org/10.1086/260266

D'Erasmo, P., \& Mendoza, E. G. (2016). Distributional Incentives in an Equilibrium Model of Domestic Sovereign Default. Journal of the European Economic Association, 14(1), $7-44$.

Diamond, P. A. (1965). National Debt in a Neoclassical Growth Model. American Economic Review, 55(5), 1126. Retrieved from bth.

Flodén, M. (2001). The effectiveness of government debt and transfers as insurance. Journal of Monetary Economics, 48(1), 81-108. https://doi.org/10.1016/S0304-3932(01)00064-2

Hein, E. (2007). Interest rate, debt, distribution and capital accumulation in a post-Kaleckian model. Metroeconomica, 58(2), 310-339.

Hein, E. (2018). Autonomous government expenditure growth, deficits, debt, and distribution in a neo-Kaleckian growth model. Journal of Post Keynesian Economics, 1-23. https://doi.org/10.1080/01603477.2017.1422389

Kaldor, N. (1955). Alternative Theories of Distribution. The Review of Economic Studies, 23(2), 83. https://doi.org/10.2307/2296292

Kalecki, M. (1938). The Determinants of Distribution of the National Income. Econometrica, 6(2), 97-112. https://doi.org/10.2307/1907142

Kalecki, M. (1954). Theory of economic dynamics: An essay on cyclical and long-run changes in capitalist economy (Reprinted). London: Routledge.

Mankiw. (2000). The Savers-Spenders Theory of Fiscal Policy. American Economic Review, 90(May), 120-125.

Modigliani, F. (1961). Long-Run Implications of Alternative Fiscal Policies and the Burden of the National Debt. The Economic Journal, 71(284), 730-755. https://doi.org/10.2307/2228247

Palley, T. I. (1997). Aggregate Demand and Endogenous Growth: A Generalized KeynesKaldor Model of Economic Growth. Metroeconomica, 48(2), 161-176.

Palley, T. I. (2012). Wealth and wealth distribution in the neo-Kaleckian growth model. Journal of Post Keynesian Economics, 34(3), 453-474. https://doi.org/10.2753/PKE01603477340304

Pasinetti, L. L. (1962). Rate of Profit and Income Distribution in Relation to the Rate of Economic Growth. The Review of Economic Studies, 29(4), 267. https://doi.org/10.2307/2296303

Pasinetti, L. L. (1989). Ricardian debt/taxation equivalence in the Kaldor theory of profits and income distribution. Cambridge Journal of Economics, 13(1), 25-36. 
Samuelson, P. A., \& Modigliani, F. (1966). The Pasinetti Paradox in Neoclassical and More General Models. The Review of Economic Studies, 33(4), 269. https://doi.org/10.2307/2974425

Steedman, I. (1972). The State and the Outcome of the Pasinetti Process. The Economic Journal, 82(328), 1387-1395. https://doi.org/10.2307/2231318

Ünveren, B., \& Sunal, S. (2015). Why is the Labor Share so Low in Turkey?: Low Labor Share in Turkey. The Developing Economies, 53(4), 272-288. https://doi.org/10.1111/deve.12089

Yakut, A. M., \& Voyvoda, E. (2017). Intertemporal CGE Analysis of Income Distribution in Turkey. ERC Working Papers in Economics, 58. 